\title{
Phylogenetic, Functional, and Geological Perspectives on Complex Multicellularity
}

\section{Citation}

Knoll, Andrew H., and David Hewitt. 2011. "Phylogenetic, Functional, and Geological

Perspectives on Complex Multicellularity." In The Major Transitions in Evolution Revisited, eds.

Brett Calcott and Kim Sterelny: 251-270. doi:10.7551/mitpress/9780262015240.003.0013

\section{Published Version}

doi:10.7551/mitpress/9780262015240.003.0013

\section{Permanent link}

http://nrs.harvard.edu/urn-3:HUL.InstRepos:34222896

\section{Terms of Use}

This article was downloaded from Harvard University's DASH repository, and is made available under the terms and conditions applicable to Open Access Policy Articles, as set forth at http:// nrs.harvard.edu/urn-3:HUL.InstRepos:dash.current.terms-of-use\#OAP

\section{Share Your Story}

The Harvard community has made this article openly available.

Please share how this access benefits you. Submit a story.

\section{Accessibility}




\title{
Phylogenetic, Functional and Geological Perspectives on Complex Multicellularity
}

\author{
Andrew H. Knoll and David Hewitt \\ Department of Organismic and Evolutionary Biology \\ Harvard University \\ Cambridge MA 02138, USA
}

\section{INTRODUCTION}

Of all the events nominated as major transitions in evolution, none has received more attention than the rise of multicellularity. In part, this is because the subject can be approached from a number of perspectives, including systematics, developmental genetics, and the fossil record. And in part, of course, it is because multicellularity shapes our perceived biological landscape and, indeed, ourselves. In this paper, we begin with brief discussion of the phylogenetic distribution of multicellular organisms in general and complex multicellular life in particular, clarifying the important distinction between the two. We argue that multicellularity per se, the transfer of individuality from one cell to a coordinated group of attached cells (Michod, 2007), was necessary for the emergence of complex multicellularity, but it was not sufficient. In ensuing discussion we offer a biophysical answer to the question of what features distinguish the biomass- and species-rich clades of complex multicellular organisms from their simpler and less diverse sister groups. Only the animals, streptophyte green algae, florideophyte red algae, brown algae and three clades of fungi have evolved active transport mechanisms for oxygen, nutrients and signaling molecules that circumvent the strong constraints imposed by diffusion. A review of the Proterozoic fossil record shows that the radiations of complex multicellular animals and algae can be linked to an Ediacaran increase in the oxygen content of the atmosphere and oceans, confirming the historical link between diffusion and the evolution of complex multicellular organisms.

\section{PHYLOGENETIC CONTEXT}

The first observation to make about multicellularity is that it does not occur in most eukaryotic clades. Patterson (1999) recognized 70 major clades of eukaryotes. 53 of these are populated exclusively by unicellular organisms, predominantly motile predators on bacteria and other particle feeders, phytoplankton, and parasites. Most of these groups have few known species, conspicuous exceptions being the ciliates (which include some simple multicellular species), dinoflagellates, and granulreticulosids (mainly foraminiferans). Even the most diverse of these groups, however, fall two orders of magnitude short of the species richness documented for the most diverse multicellular clades ${ }^{1}$. Given the ecological and evolutionary success of

\footnotetext{
${ }^{1}$ Very likely, protistan diversity remains largely undocumented, with many experts estimating true species numbers an order of magnitude larger than those already described (e.g., the
} 
single cells in these groups, the presence of multicellularity in Patterson's remaining 17 clades requires functional explanation. Nine of the 17 groups include simple filaments, hollow balls, sheets, or colonies organized by branching stalks. Patterson (1999) discussed stramenopiles (a large clade that includes the brown algae, diatoms, chrysophytes and a number of other groups, both algal and heterotrophic), Viridoplantae (all green algae and their descendants, the embryophytic land plants), and opisthokonts (animals, fungi and their close protistan relatives) as single entities, and subdivision of these megaclades increases this number to 13 or more. Most are algal, although stalked colonial particle feeders have evolved at least three times, and simple filamentous fungi are absorptive heterotrophs. The widely discussed selective advantages of predator avoidance and positional effects provide a reasonable functional explanation for most. In colonial heterotrophs such as the stalked ciliate Epistylis or mixotrophic chrysophytes, feeding may be facilitated by the coordinated beating of flagella. Complex multicellular organisms evolved from simple multicellular ancestors, but not all groups with simple multicells gave rise to complex descendants. In fact, most did not.

An additional four groups have achieved multicellularity via aggregation during one stage of the life cycle. Five others (two algal, three heterotrophic) have adopted coencytial organization to achieve quasi-multicellularity and, in some cases, macroscopic size. There is no evidence that any of these evolved from simple multicellular ancestors; nor have any spawned complex multicellular descendants.

Collectively, simple multicellular organisms form a heterogeneous grouping that defies simple phylogenetic, functional or developmental categorization. Indeed, we might choose to define many of these groups out of the discussion, depending on whether we insist that multicellularity include intercellular connections and/or cell differentiation. We prefer to deal them in, as they record important comparative biological information about the roads to (and in some cases, away from) complex multicellularity.

Most groups with simple multicellularity share several properties. Adhesive molecules (or, as in some filamentous diatoms, simple interlocking of wall protuberances) connect adjacent cells. Even with these physical attachments, however, communication and transfer of resources among cells and cellular differentiation are limited in some groups, absent in others. The multicellular state is both functional and persistent in these groups, and it appears to confer selective advantage. The penalty for loss of constituent cells, however, is commonly small. Michod (2006) modeled the emergence of multicellularity in terms of a downwardly convex curve relating fecundity and viability. Initially, increasing cell number may promote viability by, say, deterring predation; as long as most or all cells retain the capacity to reproduce, mean cell fitness will remain high. With increasing differentiation, however, mean cell fitness can decline even as mean cell viability continues to increase, due to reduction of per-cell fecundity -

diatoms, with 10,000 described and 100,000 estimated species, many of them simple filaments; Kooistra et al., 2007). The same, however, is true of the animals and complex fungi, so that protistan diversity would need to be underdescribed by more than two orders of magnitude for unicellular and simple multicellular species to match the diversity of complex multicellular species. 
hence the convex shape of Michod's curve. As long as viability gain exceeds fecundity loss, overall fitness will increase, favoring multicellurity.

Importantly, for reasons discussed below, every cell in simple multicellular organisms is in direct contact with the external environment, at least during phases of the life cycle characterized by nutrient acquisition and active metabolism.

In contrast, complex multicellularity has evolved in animals, fungi (at least three times; Hewitt, 2007), green algae, red algae, and brown algae. Species in these clades show evidence of cell-cell adhesion, intercellular communication (e.g., gap junctions, plasmodesmata), and cellular and tissue differentiation mediated by networks of regulatory genes. Programmed cell death occurs in a number of these groups (as it does in some unicellular clades; e.g., Vardi et al., 1999), but unprogrammed cell or tissue loss can be lethal for the entire organism - perhaps more so in metazoans than in other groups with persistent stem cells. Notably, organisms in these clades display a multicellular organization in which only some cells are in direct contact with the environment.

The presence of exterior and interior cells is, in our view, critical. In consequence, cells do not all have equal access to nutrients and therefore will not accumulate biomass at a uniform rate - unless a mechanism evolves for the transfer of resources from one cell to another. Also, interior cells no longer receive signals directly from the environment, even though response to environmental dynamics remains key to growth, reproduction, and survival. Complex multicellular organisms, therefore, require mechanisms by which environmental signals can be received by surficial cells and transduced to interior cells, where genes will be up- or down regulated in response. Of course, development in complex multicellular organisms can be defined as up- or down regulation of genes in response to molecular signals from surrounding cells. In animals or plants, the effective environment of most cells is cellular, but signaling between adjacent cells may derive from fundamental mechanisms of signal transduction evolved in response to a need for life history regulation (Knoll and Bambach, 2000; Schlichting 2003; see below).

Only active transfer processes will free multicellular organisms with interior and exterior cells from the sharp constraints of molecular diffusion. Inspection of the three plots in Figures 1 and 2 shows that, indeed, the circumvention of diffusion by active transport of metabolites and molecular signals differentiates biomass- and species-rich clades of eukaryotes from their less diverse sister groups. Within the Streptophyta (Fig. 1A), for example, the three basal clades of unicells (Mesostigmatales), sarcinoid colonies (Chlorokybales), and simple filaments (Klebsormidiales) have only a few dozen species among them. More distal branches include the Zygnematales [ca. 6000 species of filamentous and (derived?) unicells] and their sister group, the megaclade characterized by complex branching, intercellular connections via plasmodesmata, and, in some cases at least, cells that are completely surrounded by other cells. This clade includes the Coleochaetales (ca. 20 species), Charales (81 species), and the most derived and three-dimensionally complex streptophytes, the embryophytes, with some 400,000 species and a collective biomass larger than all other eukaryotes combined. Similar patterns of species richness and biomass characterize the red (Fig. 1B) and brown algae, metazoans and their sister groups, and fungi (Fig. 2). High abundance and diversity reflect the functional 
possibilities of three-dimensional organization (Niklas, 1994; Marshall, 2005), shaped by evolvable networks of regulatory genes (Gerhart and Kirschner, 2007), but fundamentally made possible by active transport mechanisms.

\section{DIFFUSION AND ITS CIRCUMVENTION}

As noted above, three-dimensional anatomical structure has the functional consequence that many cells within the individual will not be in direct contact with their physical environment. Interior cells will not have access to the same nutrients or environmental signals as surface cells, and the extent of interior privation will be a direct function of diffusion.

\section{Metabolism}

Bacteria are metabolic machines adapted for a world of intermittent resource availability (e.g., Knoll and Bauld, 1989). Fitness in bacteria is a strong function of metabolic rate when resources are present, and metabolic rate, in turn, reflects resource diffusion into the cell. Commonly, therefore, bacterial cells tend toward a high ratio of surface area to volume (by being small) and are everywhere in contact with the surrounding environment. Archaea appear to take this a step further, being adapted for environments where energy availability is limited (Valentine, 2007). Under these conditions, it is not surprising that cell differentiation and complex, three-dimensional multicellularity are poorly developed in the prokaryotic domains.

Diffusion also constrains function in eukaryotic organisms, with $\mathrm{P}_{\mathrm{O} 2}, \mathrm{P}_{\mathrm{CO} 2}$, availability of fixed nitrogen, and concentrations of sugars or other metabolizable organic substrates all imposing potential constraints on size. Oxygen provides a particularly illuminating example, and is in fact unique as there are no transmembrane pumps that permit $\mathrm{O}_{2}$ concentrations to build internally against a concentration gradient. Catling et al. (2005) have spelled out in detail why oxygen is a universal requirement for large multicellular organisms. Only the oxidation of organic molecules by $\mathrm{O}_{2}$ provides sufficient energy to build a food chain that includes energyintensive, macroscopic heterotrophs, and only oxygen in concentrations approaching those of the present day permits the oxygenation of interior cells in macroscopic organisms limited by diffusion $^{2}$. Indeed, on this planet, no other oxidant exhibits both comparable abundance and energy gain from respiration -- for large complex heterotrophs, there is no metabolic alternative to oxygen.

The constraints placed by oxygen diffusion on organism size were recognized nearly a century ago (Krogh, 1919; Graham, 1988). The thickness of cells or tissues that can be oxygenated by diffusion is a function of mass-specific metabolic rate (how rapidly oxygen is

\footnotetext{
${ }^{2}$ Under the specific conditions where fermentable substrates are present in high concentration, the high rates of ATP production by fermenters may provide selective advantage over respirers in the same environment (Pfeiffer et al. 2001), but at the time(s) when multicellularity arose, such environments must have been a small subset of available habitats. Yeasts, for example, are thought to have evolved only 120-65 million years ago, in response to the evolution of sugar-rich angiosperm fruits (Thomson et al., 2005).
} 
used) and the partial pressure of oxygen in the ambient environment (how much oxygen is available for use). In shallow marine waters in direct contact with today's atmosphere, $\mathrm{O}_{2}$ diffusion limits tissue thickness to ca. $1 \mathrm{~mm}$ to $1 \mathrm{~cm}$, depending on metabolic rate (Figure 2; Raff and Raff, 1970; Runnegar, 1991). Severe or prolonged hypoxia causes cell death in animals, and it also appears to activate signaling pathways (Blackstone, 2001), including those that cause unprogrammed cell proliferation (Harris, 2001; Saul and Schwartz, 2007).

Inward diffusion of metabolizable organic molecules will also limit tissue thickness in heterotrophs, and $\mathrm{CO}_{2}$, light, and nutrient (e.g., nitrate or ammonia) penetration will do the same in autotrophs. [Even in the simple multicellular alga Volvox, coordinated beating of flagella is required to circumvent diffusive limitation by modifying the surface boundary layer (Short et al., 2006).] The key point is that three-dimensionality potentially opens up a universe of new functional possibilities, but this potential can only be realized if resources needed for growth and reproduction can be transported among cells.

In green, red and brown algae, intercellular transport is facilitated by plasmodesmata, ER-containing strands of cytoplasm that connect adjacent cells via pits in cell walls (Table 1). Algae also have membrane pumps that can move bicarbonate and other simple molecules across cell boundaries against a concentration gradient. Fungi commonly have incomplete cell walls that facilitate intercellular transfer of metabolites, whereas animals, lacking cell walls, have gap junctions and other protein-modulated modifications of cell membranes to govern molecular traffic between cells. Within these clades, some groups have evolved specialized cell and tissue types for long distance transfer of metabolites: phloem in vascular plants, trumpet hyphae in brown algae, rhizomorphs in fungi (Cairney 2005) and complex circulatory systems in animals (Table 1). Most fungi have the capacity for metabolite transfer across short distances, but fossils of meter-scale fungi that stood out like giants in Devonian landscapes contain networks of wide tubular cells that likely facilitated transfer of metabolites from mycelia to fruiting bodies (Boyce et al., 2007). Animals have also elaborated specialized surfaces (Graham, 1988) to facilitate oxygen intake and oxygen-binding pigments that are transported throughout the body by fluids.

\section{Development}

Schlichting (2003) recognized the consequences of three-dimensional growth for cell differentiation and, hence, development. As in the case of metabolism, these consequences stem from the fact that in three-dimensional multicellular organisms, only a subset of all cells is in direct contact with the environment. Many (but not all) of the signaling molecules employed by plants and animals occur in unicellular organisms found on closely related branches of phylogenies. For example, a number of gene families implicated in cell signaling and adhesion have been discovered in choanoflagellates (Segawa et al., 2006; King et al., 2008; Abedin and King, 2008). Similarly, BIP2-like proteins known to regulate development in seed plants have been identified in the unicellular streptophyte Mesostigma (Nedelcu et al., 2006). MiRNAs that function in the regulation of vascular plant development have also been reported from the unicellular green alga Chlamydomonas (Molnar et al., 2007). For the most part, the functions of these protistan genes remain unknown, but many are likely active in mediating morphological and cytological changes associated with life cycle variation (Knoll and Bambach, 2000; Schlichting, 2003; King, 2004; Ruiz-Trillo et al., 2007). An elegant example of this was 
provided by Nedelcu and Michod (2006), who showed that the gene regA, which regulates terminal somatic differentiation in Volvox carteri, has a homolog in its close unicellular relative Chlamydomonas reinhardtii that may function in life cycle differentiation. Other signals adapted for multicellular development may have originated for signaling among cells in local populations, as seen, for example, in transient colony formation by the basal opisthokont Sphaeroforma (Ruiz-Trillo et al., 2007).

As Schlichting (2003) explained, three-dimensional growth has the consequence that interior cells will modify gene expression in response to external environmental change only if signals can be transduced to the interior from surficial cells that directly perceive environmental change. Moreover, the perceived physical and chemical environment of interior cells will differ from that of surface cells because nutrients, oxygen, and light will all be attenuated at depth. In a number of protists, non-motile, sexual stages of the life cycle are induced by nutrient or oxygen privation, raising the possibility that simple cell differentiation in multicellular organisms might originally have occurred as a direct consequence of three-dimensional multicellularity. In this context, it is important to note that differentiation into two cell types is not an evolutionary milestone of multicellular organisms. Many unicellular organisms have life cycles in which different cell types alternate in time - the innovation of multicellular organisms is the spatial (and not only temporal) differentiation of cells.

Reactive oxygen species (ROS) act as developmental signals in both macroscopic and microscopic eukaryotes (Blackstone, 2000; Aguirre et al., 2005), and, in animals at least, hypoxia-induced ROS can trigger the proliferation of cancerous cells (Saul and Schwartz, 2007, and references therein). Thus, in early organisms with multiple cell layers, active regulation may have been necessary not so much to induce differentiation but to prevent - or at least control - spontaneous differentiation along an unprogrammed signaling gradient.

In effect, in three-dimensionally complex organisms, the ambient environment of interior cells is other cells, and genetic up- and down regulation reflects perceived environmental gradients and signals from surrounding cells - the very definition of development. Moreover, signals generated by surface cells will diffuse inward, setting up a molecular gradient that will induce different genetic responses in cells along the gradient - again the essence of development in plants and animals (Schlichting, 2003). Active transport [for example, auxin transport in plants (Sieberer and Leyser, 2006) or thyroid hormone action in animals (Feldt-Rasmussen and Rasmussen, 2007), not to mention bulk transport by circulatory systems or vascular tissue] will increase the distance over which signaling can occur, again circumventing the limitations of diffusion and introducing topologically specific patterns of differentiation along the path of signal transport.

\section{A Positive Feedback Loop}

The obvious chicken-and-egg problem is whether size increase reflects or promotes the active transfer of nutrients, oxidants, and cell signals. The solution may be to consider the system of size, metabolism, and differentiation as a positive feedback loop. 
Under a given set of environmental conditions (e.g., ambient oxygen and nitrogen concentrations), the size of an emerging multicellular organism will be limited, in the first instance, by diffusion. Plasmodesmata, gap junctions or other mechanisms will increase the allowable thickness of tissues by facilitating the transfer of metabolites and signaling molecules between adjacent cells. The length scale on which such transfer will be effective is, however, small. Moreover, the degree to which oxygen and diffusible nutrients will be available to interior cells will remain a function of diffusion.

It is important here to reiterate that there are no transmembrane pumps that permit $\mathrm{O}_{2}$ concentrations to build internally against a concentration gradient; therefore, oxygen is a special case among molecular requirements, in that bulk flow of dissolved oxygen is required for long distance transport. As discussed below, this means that ambient oxygen levels must have exerted an important control on size and shape in emerging multicellular organisms.

At small sizes, direct cell-cell connections may be sufficient to support interior cells in three-dimensional organisms. Increasing thickness, however, will enlarge the distance between surface and interior, setting up an increasingly strong gradient of nutrients and signaling molecules. As noted above, this gradient may itself promote cell differentiation, and cells which differentiate in ways that facilitate molecular transfer will potentiate further size increase (e.g. Bell and Mooers, 1997). In this way, size and cell differentiation can populate a positive feedback loop, governed by metabolic and signaling gradients, that will eventually carry populations across a functional threshold - to the size and complexity of vascular plants, for example, or bilaterian animals.

\section{A GEOLOGICAL PERSPECTIVE}

The fossil record for the first half of Earth history is poor. An Archean origin for eukaryotes has been postulated on the basis of geochemical signatures for methanogenic Archaea in rocks as old as $2.7 \mathrm{Ga}$ and small subunit rRNA gene trees that place eukaryotes as sister to the archaeans. Consistent with this, steranes of probable eukaryotic derivation have been reported from 2.7 Ga rocks (Brocks et al., 1999). Both the phylogenetic relationships of Archaea and eukaryotes (Cox et al., 2008) and the syngenicity of Archean steranes (Rasmussen et al., 2008; but see Waldbauer et al., 2009) remain topics of active debate. Moreover, at least some (hotly contested) models of eukaryiogenesis rely on ur-symbiosis between a methanogen and facultatively aerobic proteobacterium. According to these models, eukaryotes cannot pre-date the origin of methanogenic archaeans, but could, in principle, postdate them by a long interval. Regardless of preferred scenario, however, the establishment of protists with mitochondria specialized for aerobic respiration -- which appears to have occurred in stem group eukaryotes -postdates the initial accumulation of oxygen in the atmosphere and surface ocean some $2.4 \mathrm{Ga}$.

When the curtain rises on the fossil record later in the Paleoproterozoic Era, eukaryotes are already present. Large ornamented unicells with wall ultrastructures known only among eukaryotes occur in 1800-1600 Ma rocks, as do simple filaments of possible eukaryotic origin (Knoll et al., 2006). The oldest putative eukaryotic macrofossil, Grypania, is best known from 1600-1200 Ma deposits but occurs in rocks as old as 1900 Ma (Han and Runnegar, 1992). Based 
on the assumption that this organism was structurally and functionally similar to the extant green alga Acetabularia, Runnegar (1991) concluded that Grypania could have lived in shallow marine environments with only a few percent of present day oxygen levels.

Bangiophyte red algae in ca. 1200 Ma cherts simultaneously record simple filamentous multicellularity, limited cell differentiation (including a cellular holdfast), and the appearance of a recognizable crown group member of a eukaryotic phylum (Butterfield, 2000). In fact, simple eukaryotic filaments are common in fossil assemblages $1000 \mathrm{Ma}$ and younger, and organisms with a three-dimensional arrangement of cells were present as early as ca. 800 million years ago (Knoll et al., 2006). Consistent with phylogenetic inference, such fossils suggest that the molecular requirements for simple multicellularity were met early and often among eukaryotes (Knoll et al., 2006).

Despite the early appearance of simple multicellularity, records of complex multicellular organisms begin only near the end of the Proterozoic Era. Simple bangiophyte red algae may occur in 1200 Ma rocks, but florideophytes with three-dimensional anatomy are first recorded in 600-560 million year old phosphatic rocks of the Doushantuo Formation, China (Xiao et al., 2004). Although simple filaments assigned to the cladophoran green algae occur in 800-750 Ma rocks from Spitsbergen (Butterfield et al., 1994), possible macroscopic greens first appear in 580-550 million year old shales (Steiner, 1994; Xiao et al. 2002). Green algae with complex three-dimensional (coenocytic) architecture enter the record only in the Cambrian (Satterthwait, 1976), whereas unequivocal embryophytes first appear in the Ordovician (Wellman and Gray 2000). More generally, macroscopic seaweeds with complex morphology began to spread across marine shelves and platforms only ca. 580-560 Ma (Xiao et al., 2002). On land, putative ascomycetes postdate the first appearances of embryophytes, but still occur in Lower Silurian rocks (Pratt et al., 1978; Sherwood-Pike and Gray, 1985). Unequivocal records of complex multicellular fungi begin with silicified fossils in the earliest Devonian Rhynie Chert (Taylor et al., 1999).

The earliest macroscopic heterotrophs are Ediacaran fossils preserved in basinal strata from Newfoundland, well dated at ca. 575 Ma (Narbonne, 2005). Many of these organisms have a distinctive architecture based on iterated tubes or cylinders. Their phylogenetic relationships are widely disputed, but stem group animals or eumetazoans constitute the current best estimate for systematic placement. As in many modern cnidarians, metabolically active tissue in these organisms may have been limited to a thin layer surrounding an inert fluid-filled or gelatinous interior. Thus, the "metabolic thickness" supported by inward diffusion of oxygen may have been considerably less than the whole-body thickness estimated from fossil casts and molds. Well-dated rocks from northern Russia place the origin of motile bilaterian animals a bit before 555 Ма (Martin et al., 2000), providing a minimum date for cm-scale animals with dense muscle tissues. Animals with biomineralized skeletons expanded globally at 548 Ma (Grotzinger et al., 2000), but only in the Cambrian did bilaterian animals with body plans comparable to those in present day oceans diversify (Budd and Jensen, 2000).

No unambiguous animal macrofossils predate $575 \mathrm{Ma}$, but microfossils push the metazoan record further back into time, and molecular biomarkers may push even further. Phosphatic sedimentary rocks in southeastern China preserve the eggs and early cleavage-stage 
embryos (Xiao and Knoll, 2000) of early, perhaps stem group (Hagadorn et al., 2006), animals. These embryos occur stratigraphically below the first macroscopic Ediacaran heterotrophs seen regionally; they may or may not be older than the first Ediacarans in Newfoundland. The Chinese embryos occur in the same beds as abundant and diverse cysts of unusual size and both morphologic and ultrastructural complexity. These cysts are distinct from those known to be produced by algae, but share many similarities with cysts formed by animals that have a resting stage in their life cycles (Cohen et al., 2009). Indeed, Yin et al. (2007) recently discovered embryos within one type of cyst. These cysts have been found in rocks well dated at $632 \mathrm{Ma}$, deepening the geological record of animals by nearly 60 million years.

Still older animals are recorded by steranes, the geologically stable carbon skeletons of sterol molecules found in ca. 650 Ma shales from Oman (Love et al., 2009). Not all steranes are taxonomically diagnostic, but sponges constitute the most likely source of sterols with 24isopropylcholestane skeletons (Love et al., 2009; Kodner et al., 2008). Found in some abundance in Oman shales, these molecules preserve a biological signature even though body fossils are absent.

We can argue forever about molecular clocks and depths of diversification they suggest (e.g., Rogers and Hug, 2006; Bronham, this volume), but rapidly accumulating geochemical evidence indicates that pre-Ediacaran environments were, at best, only intermittently conducive to large aerobic heterotrophs (e.g., Fike et al., 2006; Canfield et al., 2007, 2008). Geochemical data suggest that atmospheric oxygen was an order of magnitude lower than current levels during most of the Proterozoic Era - empirically, the oxygen minimum layer in Proterozoic oceans showed a strong statistical tendency toward euxinia (e.g., Canfield, 1998; Anbar and Knoll, 2002; Shen et al., 2003; Arnold et al., 2004; Brocks et al., 2005; Scott et al., 2008). Oxygen may have begun its second phase of increase early in the Neoproterozoic Era, but available evidence suggests that any Neoproterozoic trajectory was not monotonic. The global distribution of early diagenetic siderite in 700-580 Ma basins (Canfield et al., 2008) strongly suggests that both oxygen and sulfate, the other great oxidant in modern oceans, were low at this time. Geochemical data further indicate that larger sulfate reservoirs and more persistently oxic deep waters began to appear about $580 \mathrm{Ma}$ and stabilized within about 20 million years (Canfield et al., 2007, 2008; Fike et al., 2006), signaling the advent of oceans with relatively modern redox chemistry.

Observation (Rhoads and Morse, 1971) and biophysical models (Runnegar, 1991) indicate that the abundances of oxygen likely for surface water masses in pre-Ediacaran oceans ( $<10 \%$ PAL) were too low to support even mm-scale cell/tissue thickness in early, diffusionlimited animals. This doesn't require that metazoans were absent from these oceans, only that they would have to be small (or at least very thin). Given the impressive complement of animal signaling and adhesion molecules in sponges and cnidarians (Nichols et al., 2006; Putnam et al., 2007) and hypotheses that derive eumetazoans from larval sponges (Maldonado, 2004), a good deal of genomic evolution and divergence could have occurred within the animal clade before the appearance of macroscopic metazoan fossils.

As noted above, large animals appear by $575 \mathrm{Ma}$ and motile bilaterians with elevated energy requirements are known soon thereafter. Interestingly, as noted above, algae with 
complex multicellularity radiate at the same time, and biomarker molecules independently indicate that eukaryotes became major contributors to primary production only in the late Neoproterozoic Era (Knoll et al., 2007). Why should low oxygen have limited the evolution of complex multicellularity in algae, which, after all generate oxygen? One obvious consideration is that algae also respire aerobically and do so at night, when they are not generating oxygen. Thus, they are subject to the same constraints of oxygen diffusion that limit heterotrophs. Moreover, oceans with redox structure like that inferred for the Proterozoic Eon would have a nitrogen cycle far different from the one we know at present. Before $580 \mathrm{Ma}$, fixed nitrogen was likely in low supply in most marine photic zones (Anbar and Knoll, 2002; Fennel et al., 2005); in its absence, algae would have competed poorly against nitrogen-fixing photosynthetic bacteria.

The foregoing observations suggest a close biophysical relationship between Earth's redox chemistry and the emergence of complex multicellular organisms. Prior to the Ediacaran Period, $\mathrm{P}_{\mathrm{O} 2}$ and, additionally for autotrophs, nutrient availability limited the number of functioning cell layers in eukaryotic organisms. Rising oxygen levels alleviated this constraint 580-560 Ma. The order of magnitude increase in $\mathrm{P}_{\mathrm{O} 2}$ inferred for this interval would have allowed the maximum volume of diffusion-limited organisms to increase by up to three orders of magnitude (Figure 2), providing ample raw material for increased anatomical complexity (cf. Bell and Mooers, 1997). That is, the latest Proterozoic rise in oxygen would have given the nudge required to set in motion the positive feedback loop of size, transport and differentiation.

In short, the long apparent lag between the appearance of simple multicellularity in eukaryotes and the radiation of groups with complex multicellular organization has an environmental component that can be linked back to the consequences of life with interior and exterior cells. Put another way, the physical environment within which natural selection occurs has changed through time in ways that greatly altered the selective value of mutations favoring three-dimensional multicellularity, with a latest Proterozoic state-shift changing the adaptive landscape irrevocably.

\section{DISCUSSION AND CONCLUSIONS}

Having outlined the biophysical requirements for complex multicellularity, we end where we began - with phylogeny. Within the eukaryotes, not all unicellular clades gave rise to simple multicells, and not all groups with simple multicellularity gave rise to organisms with complex multicellularity. Yet, complex multicellular eukaryotes dominate both species diversity and biomass within the domain.

Why have only a few eukaryotic clades evolved complex multicellularity? Understanding why some things don't evolve is challenging, as exemplified by Richard Lewontin's (2003) famous question: why are there no grass-eating snakes? In combination with phylogeny, however, the positive feedback scenario outlined above may be instructive.

Complex multicellularity requires adhesion between cells, communication between cells, and a genetic program for cell differentiation. The capacity of cells to respond to external signals by remodeling is widespread among unicellular eukaryotes, suggesting that at least the rudiments 
of developmental program predate multicellularity. Molecules that promote cell-cell adhesion also occur widely in originally unicellular clades, where these molecules may well serve other functions (e.g., King et al., 2008).

Given these distributions, two key steps stand out as key to the emergence of complex multicellularity. First was the establishment of mechanisms for active molecular transport between adjacent cells. Of the 17 eukaryotic clades known to include simple multicellular organisms, only five have plasmodesmata, gap junctions, or incomplete cell walls that facilitate cell-cell communication, and all complex multicellular organisms belong to these five clades.

The second required step, achieved in all groups with intercellular transport mechanisms, was the differentiation of mechanisms for the bulk transfer of oxygen through tissues. The circumvention of diffusion made possible by these innovations provided the jumping-off point for functionally and anatomically complex multicellular organisms.

This perspective reemphasizes a point made earlier by McShea (2002) and others: the evolutionary transition from unicells to complex multicellular organisms has several steps -- it is a corridor, not a door. The entrance is marked by genetically mediated, geometrically regular multicellular colonies that derive some fitness benefit from their geometry but pay little penalty for ontogenetic mistakes. Marcot and McShea (2007) have rightly viewed this as a minor transition, as it is commonly reversible ${ }^{3}$. Simple multicells appear to be necessary prerequisites for complex multicellular organisms, but they are not sufficient. The required boost comes from three-dimensionality. Positive feedbacks involving size, signal and materials transfer, and development propel clades toward the exit of the corridor, marking the truly major transition to complex multicellularity. Development underpins the establishment of "irreducible complexity" (Michod, 2007), where unprogrammed cell proliferation or death can impose a severe penalty on fitness.

Of course, development also makes possible the innovations in structural support, food acquisition, and reproduction that collectively explain the high species richness and extensive biomass of complex multicellular organisms.

In conjunction with biophysical observation and modeling, the geologic record suggests that another door had to be opened along the path to complex multicellularity, this one environmental. Organismic fitness depends on environment as well as phenotype, and physical environments conducive to large size and developmental complexity may not have appeared until life on Earth was already more than three billion years old. By evolving active transport mechanisms that circumvent the strong biophysical constraints of diffusion, complex multicellular organisms reshaped the biosphere.

${ }^{3}$ Diatoms provide an illustrative example. Many diatoms species occur as chains (or, less commonly, fans) of cells in nature, presumably to evade predation and/or to maintain a particular position with respect to their environment. Breakdown of chains in culture is common, causing no ill effects on populations. Interestingly, the one major diatom clade made up almost exclusively of unicells is the raphid pennates, a highly derived clade characterized by flagellar motion of vegetative cells (Kooistra et al., 2007). 


\section{ACKNOWLEDGEMENTS}

We thank participants in the KLI workshop on major transitions for stimulating discussion and both Kim Sterelny and Jochen Brocks for helpful reviews of our manuscript. Research leading to this paper was supported in part by NSF grant EAR-0420592.

\section{REFERENCES}

Abedin M, King N (2008) The premetazoan ancestry of cadherins. Science 319: 946948.

Aguirre J, Ríos-Momberg M, Hewitt D, Hnasberg W (2005) Reactive oxygen species and development in microbial eukaryotes. Trends Microbiol. 13: 111-118.

Anbar AD, Knoll, AH (2002) Proterozoic ocean chemistry and evolution: a bioorganic bridge? Science 297: 1137-1142.

Arnold GL, Anbar AD, Barling J, Lyons, TW (2004) Molybdenum isotope evidence for widespread anoxia in mid-Proterozoic oceans. Science 304: 87-90.

Blackstone NW (2000) Redox control and the evolution of multicellularity. BioEssays 22: 947953.

Blackstone NW (2001) Redox state, reactive oxygen species and adaptive growth in colonial hydroids. J. Exper. Biol. 204: 1845-1853.

Bell G, Mooers AO (1997) Size and complexity among multicellular organisms. Biol. J. Linn. Soc. 60: 345-363.

Boyce CK, Hotton CL, Fogel ML, Cody GD, Hazen RM, Knoll AH, Hueber FM (2007)

Devonian landscape heterogeneity recorded by a giant fungus. Geology 35: 399-402.

Bronham L (2009) This volume.

Budd GE, Jensen S (2000) A critical reappraisal of the fossil record of the bilaterian phyla. Biol. Rev. 75: 253-295.

Brocks JJ, Logan GA, Buick R, Summons RE (1999) Archean molecular fossils and the early rise of eukaryotes. Science 285: 1033-1036. 
Brocks JJ, Love GD, Summons RE, Knoll AH, Logan GA, Bowden S (2005) Biomarker evidence for green and purple sulfur bacteria in an intensely stratified Paleoproterozoic ocean. Nature 437: 866-870.

Butterfield NJ (2000) Bangiomorpha pubescens n. gen., n. sp.: implications for the evolution of sex, multicellularity and the Mesoproterozoic/Neoproterozoic radiation of eukaryotes.

Paleobiology 26: 386-404.

Butterfield NJ, Knoll AH, Swett K (1994) Paleobiology of the Neoproterozoic Svanbergfjellet Formation, Spitsbergen. Fossils and Strata 34: 1-84.

Canfield DE (1998) A new model for Proterozoic ocean chemistry. Nature 396: 450-453.

Canfield DE, Poulton SW, Narbonne GM (2007) Late-Neoproterozoic deep-ocean oxygenation and the rise of animal life. Science 315: 92-95.

Canfield DE, Poulton SW, Goldberg T, Knoll AH, Narbonne GM, Ross G, Strauss H (2008) Ferruginous conditions dominated later Neoproterozoic deep-water chemistry. Science 321: 949952.

Cairney JWG (2005) Basidiomycete mycelia in forest soils: dimensions, dynamics and roles in nutrient distribution. Mycol. Res. 190: 7-20.

Catling DC, Glein CR, Zahnle KJ, McKay, CP (2005) Why $\mathrm{O}_{2}$ is required by complex life on habitable planets and the concept of planetary “oxygenation time.” Astrobiology 5: 415-438.

Cohen PA, Kodner R, Knoll AH (2009) Ediacaran acritarchs as animal resting cysts. Proc Nat Acad Sci, USA:_doi:10.1073/pnas.0902322106

Cox CJ, Foster PG, Hirt RP, Harris SR, Embley TM (2008) The archaebacterial origin of eukaryotes. Proc Nat Acad Sci, USA 105: 20356-20361.

Feldt-Rasmussen U, Rasmussen AK (2007) Thyroid hormone transport and actions. In: Diseases of the Thyroid in Childhood and Adolescence (Krassas GE, Rivkees SA Kiess W, eds), pp 80-103. Basel: Karger, Pediatr Adolesc Med Vol 11.

Fennel K, Follows M, Falkowski PG (2005) The co-evolution of the nitrogen, carbon and oxygen cycles in the Proterozoic ocean. Am. J. Sci. 305: 526-545.

Fike DA, Grotzinger JP, Pratt LM, Summons RE (2006) Oxidation of the Ediacaran ocean. Nature 444: 744-747.

Gerhart J, Kirschner M (2007) The theory of facilitated variation. Proc. Nat. Acad. Sci. USA, Suppl. 104: 8582-8589. 
Graham JB (1988) Ecological and evolutionaery aspects of integumentary respiration: Body size, diffusion, and the Invertebrata. Amer. Zool. 28: 1031-1045.

Grotzinger, J.P., Watters W.A. and Knoll A.H. (2000) Calcified metazoans in thrombolitestromatolite reefs of the terminal Proterozoic Nama Group, Namibia. Paleobiology 26, 334-359.

Hagadorn JW, Xiao S, Donoghue PCJ, et al. (2006) Cellular and subcellular structure of Neoproterozoic animal embryos. Science 314: 291-294.

Han TM, Runnegar B (1992) Megascopic eukaryotic algae from the 2.1-billion-year-old Negaunee Iron-Formation, Michigan. Science 257: 232-235.

Harris AL (2001) Hypoxia - a key regulatory factor in tumour growth. Nature Reviews: Cancer 2: 38-47.

Hewitt D (2007) Ph.D. Thesis, Harvard University, Cambridge MA.

King $\mathrm{N}$ et al (2008)The genome of the choanoflagellate Monosiga brevicollis and the origin of metazoans. Nature 451: 783-788.

Knoll AH, Bauld, J (1989) The evolution of ecological tolerance in prokaryotes. Trans. R. Soc. Edinburgh 80: 209-223.

Knoll AH, Bambach RK (2000) Directionality in the history of life: diffusion from a left wall or repeated scaling of the right? Paleobiology, Suppl. 26(4): 1-14.

Knoll AH, Javaux EJ, Hewitt D, Cohen, P (2006) Eukaryotic organisms in Proterozoic oceans. Phil. Trans. R. Soc. B 361: 1023-1038.

Knoll AH, Summons RE, Waldbauer J, Zumberge J (2007) The geological succession of primary producers in the oceans. In: The Evolution of Primary Producers in the Sea (Falkowski P, Knoll AH, eds), pp 133-163. Burlington: Elsevier.

Kodner RB, Summons RE, Pearson A, King N, Knoll AH (2008) Sterols in a unicellular relative of the metazoans. Proc Nat Acad Sci, USA 105: 9897-9902.

Kooistra WHCF, Gersonde R, Medlin LK, Mann DG (2007) The origin and evolution of the diatoms: their adaptation to a planktonic existence. In: The Evolution of Primary Producers in the Sea (Falkowski P, Knoll AH, eds), pp 207-249. Burlington: Elsevier.

Krogh A (1919) The rate of diffusion of gases through animal tissues, with some remarks on the coefficient of invasion. J. Physiol. 52: 391-408.

Lewontin R (2003) Four complications in understanding the evolutionary process. Santa Fe Bull: 18: $20-26$. 
Love GD et al. (2006) Fossil steroids record the appearance of Demospongiae during the Cryogenian period. Nature 457: 718-721.

Maldonado M (2004) Chonaoflagellates, choanocytes, and animal multicellularity. Invert. Biol. 123: 1-22.

Marcot JD, McShea DW (2007) Increasing hierarchical complexity through the history of life: phylogenetic tests of trend mechanisms. Paleobiology 33: 182-200.

Marshall CR (2005) Explaining the Cambrian "explosion" of animals. Ann. Rev. Earth Planet. Sci. 34: 355-384.

Martin MW, Grazhdankin DV, Bowring SA, Evans DAD, Fedonkin MA, Kirschvink JL (2000) Age of Neoproterozoic bilaterian body and trace fossils, White Sea, Russia: Implications for metazoan evolution. Science 288: 841-845.

McShea, DW (2002) A complexity drain on cells in the evolution of multicellularity. Evolution 56: 441-452.

Michod RE (2006) The group covariance effect and fitness trade-offs during evolutionary transitions in individuality. Proc. Nat. Acad. Sci. USA 103: 9113-9117.

Michod RE (2007) Evolution of individuality during the transition from unicellular to multicellular life. Proc. Nat. Acad. Sci. USA, Suppl. 104: 8563-8676.

Molnar A, Schwach F, Studholme DJ, Thuenemann EC, Baulcombe DC (2007) MiRNAs control gene expression in the single-cell alga Chlamydomonas reinhardtii. Nature 447: 1126-1129.

Narbonne GM (2005) The Ediacara biota: Neoproterozoic origin of animals and their ecosystems. Ann. Rev. Earth Planet. Sci. 33: 421-442.

Nedelcu AM, Michod RE (2006) The evolutionary origin of an altruistic gene. Mol. Biol. Evol. 23: 1460-1464.

Nedelcu AM, Borza T, Lee RW (2006) A land plant-specific multigene family in the unicellular Mesostigma argues for its close relationship to Streptophyta. Mol. Biol. Evol. 23: 1111-1015.

Nichols SA, Dirks W, Pearse JS, et al. (2006) Early evolution of animal cell signaling and adhesion genes. Proc. Nat. Acad. Sci. USA 103: 12451-12456.

Niklas KJ (1994) Morphological evolution through complex domains of fitness. Proc. Nat. Acad. Sci. USA 91: 6772-6779.

Patterson DJ (1999) The diversity of eukaryotes. Amer. Nat. 154, Suppl.: S96-S124 
Pfeiffer T, Schuster S, Bonhoeffer S (2001) Cooperation and competition in the evolution of ATP-producing pathways. Science 292: 504-7.

Pratt LM, Phillips TL, Dennison JM (1978) Evidence of non-vascular land plants from Early Silurian (Llandoverian) of Virginia, USA. Rev. Palaeobot. Palynol. 25: 121-149.

Putnam NH, et al. (2007) Sea anemone genome reveals ancestral eumetazoan gene repertoire and genomic organization. Science 317: 86-94.

Raff RA, Raff EC (1970) Respiratory mechanisms and the metazoan fossil record. Nature 228: 1003-1005.

Rasmussen B, Fletcher IR, Brocks JJ, Kilburn MR (2008) Reassessing the first appearance of eukaryotes and cyanobacteria. Nature 455: 1101-1104.

Rhoads DC, Morse JW (1971) Evolutionary and ecologic significance of oxygen-deficient marine basins. Lethaia 4: 413-428.

Roger AJ, Hug LA (2006) The origin and diversification of eukaryotes: problems with molecular phylogenetics and molecular clock estimation. Phil. Trans. Royal Soc. B 361: 1039-1054.

Ruiz-Trillo I, Burger G, Holland PWH, King N, Lang BF, Roger AJ, Gray M (2007) The origins of multicellularity: a multi-taxon genome initiative. Trends Genetics 23: 13-118.

Runnegar B (1991) Precambrian oxygen levels estimated from the biochemistry and physiology of early eukaryotes. Paleogeogr. Palaeoclimatol. Palaeoecol. 97: 97-111.

Satterthwait DF, 1976. PhD thesis, University of California, Los Angeles CA, USA.

Saul JM, Schwartz L (2007) Cancer as a consequence of the rising level of oxygen in the Late Precambrian. Lethaia 40: 211-220.

Sherwood-Pike MA, Gray J (1985) Silurian fungal remains - probable records of the Class Ascomycetes. Lethaia 18: 1-20.

Schlichting CD (2003) Origins of differentiation via phenotypic plasticity. Evol. Develop. 5: 98105.

Scott C, Lyons TW, Bekker A, Shen Y, Poulton SW, Chu X, Anbar AD (2008) Tracing the stepwise oxygenation of the Proterozoic ocean. Nature 452: 456-458.

Shen Y, Knoll AH, Walter MR (2003) Evidence for low sulphate and deep water anoxia in a mid-Proterozoic marine basin. Nature 423: 632-635. 
Short MB, Solari CA, Ganguly S, Powers TR, Kessler JO, Goldstein RE (2006) Flows driven by flagella of multicellular organisms enhance long-range molecular transport. Proc. Nat. Acad. Sci. USA 103: 8315-8319.

Sieberer T, Leyser O (2006) Auxin transport, but in which direction? Science 312: 858-860.

Steiner M (1994) Die neoproterozoischen Megaalgen Sudchinas. Berliner geowissenschaftliche Abhandlungen (E) 15: 1-146.

Taylor TN, Hass H, Kerp H (1999) The oldest fossil ascomycetes. Nature, 399: 648.

Thomson JM, Gaucher EA, Burgan MF, De Kee DW, Li T, Aris JP, Benner SA (2005) Resurrecting ancestral alcohol dehydrogenases from yeast. Nature Genetics 37: 630-635.

Valentine DL (2007) Adaptations to energy stress dictate the ecology and evolution of the Archaea. Nature Reviews Microbiol. 5: 316-323.

Vardi A, Berman-Frank I, Rozenberg T, Hadas O, Kaplan A, Levine A (1999) Progammed cell death of the dinoflagellate Peridinium gatunense is mediated by $\mathrm{CO}_{2}$ limitation and oxidative stress. Curr. Biol. 9: 1061-1064.

Waldbauer JR, Sherman LS, Sumner DY, Summons RE (2009) Late Archean molecular fossils from the Transvaal Supergroup record the antiquity of microbial diversity and aerobiosis. Precambrian Research 169: 28-47.

Wellman CH, Gray J (2000) The microfossil record of early land plants. Phil. Trans. Royal Soc. B 355: 717-731.

Xiao S, Knoll AH (2000) Phosphatized animal embryos from the Neoproterozoic Doushantuo Formation at Weng'an, Guizhou Province, South China. J. Paleontol. 74: 767-788.

Xiao S, Yuan X, Steiner M, Knoll AH (2002) Macroscopic carbonaceous compressions in a terminal Proterozoic shale: a systematic reassessment of the Miaohe biota, South China. J. Paleontol. 76: 345-374.

Xiao S, Knoll AH, Yuan X, Pueschel CM (2004) Phosphatized multicellular algae in the Neoproterozoic Doushantuo Formation, China, and the early evolution of florideophyte red algae. Am. J. Bot. 91: 214-227.

Yin L, Zhu M, Knoll AH, Yuan X, Zhang J, Hu J (2007) Doushantuo embryos preserved within diapause egg cysts. Nature 446: 661-663. 


\section{Complex Multicellularity: Phylogenetic, Functional and Geological Perspectives}

Andrew H. Knoll and David Hewitt

\section{TABLE}

Table 1: Cell structures and cell/tissue types that promote active transport of metabolites and signaling molecules in complex multicellular eukaryotes.

Taxon

Streptophyte green algae/

Embryophytes

Florideophyte red algae

Brown algae

Fungi

Metazoans
Cell-cell connections plasmodesmata

plasmodesmata

plasmodesmata

septal pores, plasmodesmata
Differentiated cells/tissue sieve cells/phloem; leptoids, hydroids

trumpet hyphae rhizomorphs, vessel hyphae circulatory system 


\section{FIGURE CAPTIONS}

Fig. 1. The distribution of species richness within the Archaeplastida. Bars indicate character evolution of three-dimensional multicellularity, with active transport of metabolites. Speciesrich clades characterized by complex multicellularity noted by grey boxes. a) Streptophytes, phylogeny adapted from Lewis and McCourt (2004), diversity values for algal streptophyte lineages from Turmel et al. (2007) and embryophyte diversity from Govaerts (2001; seed plant diversity: 422,000; lower bound estimate cited as 231,000), Schneider et al (2004; fern diversity: 10,000) and Renzaglia (2007; liverwort diversity: $\sim 5,200$, moss diversity: $\sim 12,800$, hornwort diversity: 5,000).

b) Species diversity in the rhodophyte lineage; phylogeny adapted from Saunders and Hommersand (2004) and Baldauf et al. (2000); diversity values from Algaebase taxonomic database (www.algaebase.org accessed August 2007); Glaucocystophyte diversity from Andersen (1992).

Estimates are for named species and do not extrapolate to unnamed diversity.

Fig. 2. The distribution of species richness within the opisthokont clade. Bars indicate character evolution of three-dimensional multicellularity, with active transport of metabolites. Speciesrich clades characterized by complex multicellularity. Euascomycetes include the majority of the fruitbody-forming ascomycetes; homobasidiomycetes include the fruitbody-forming basidiomycetes. Phylogeny adapted from Baldauf et al (2000) and Blackwell et al (2007); diversity values for fungal lineages from Mueller and Schmit (2007), except for Taphrina diversity, which is from Rodrigues and Fonseca (2003); metazoan diversity from Wilson (1999); choanoflagellate diversity from Maldonado (2004). Estimates are of named species and do not extrapolate to unnamed diversity.

Fig. 3. Diagram showing the empirically-derived relationship between mass-specific metabolic rates for aerobically respiring organisms and the maximum radius of a spherical organism dependent on diffusion for the oxygenation of internal cytoplasm/cells; the high angle lines indicate the predicted limits on metabolic rate and size when (from right to left) $\mathrm{P}_{\mathrm{O} 2}$ is $1.0 \mathrm{x}$ present atmospheric level (PAL), 0.1 PAL and 0.01 PAL (redrawn from Runnegar, 1991). The cartoon on the right emphasizes the inward-decreasing gradient of metabolites and signaling molecules expected for diffusion-limited organisms.

Fig. 4. Diagram showing the stratigraphic record of simple and complex multicellular eukaryotes; see text and Knoll et al. (2006) for discussion. 


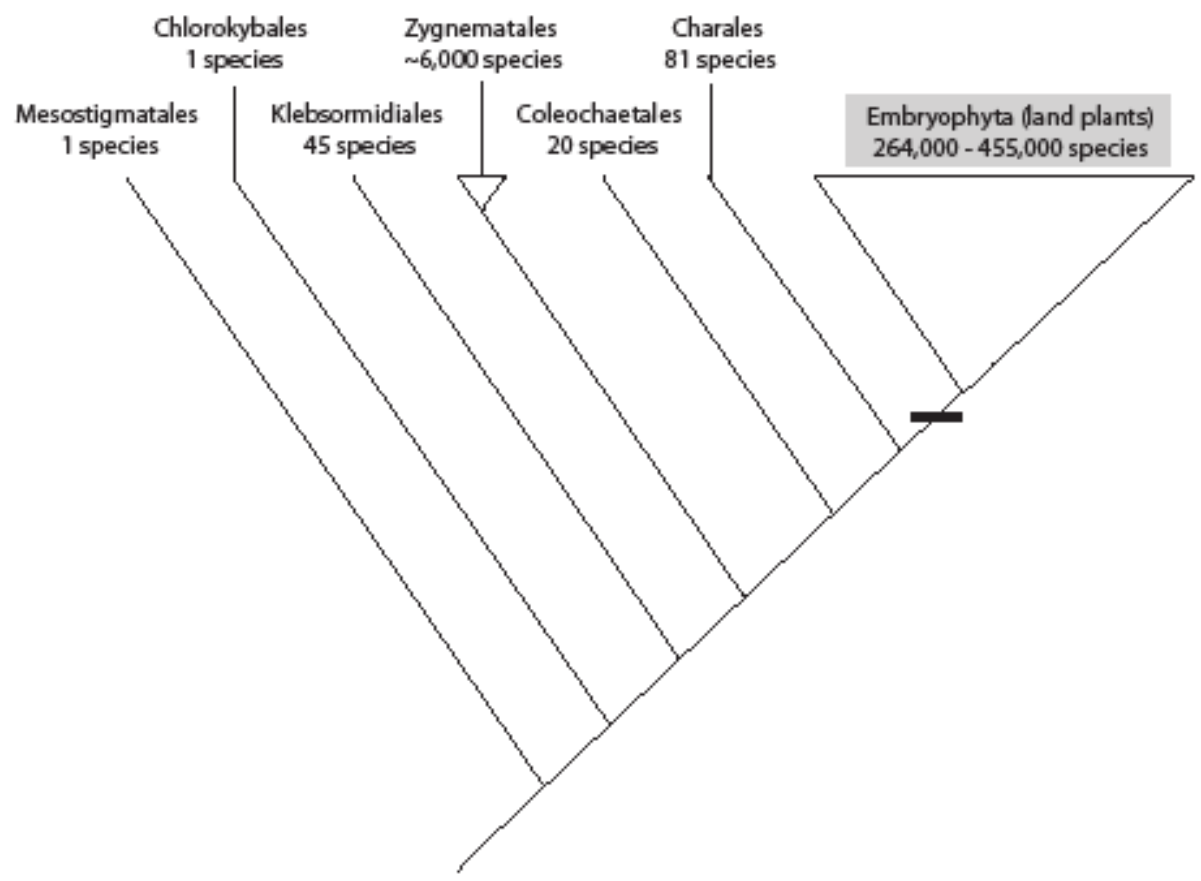

A

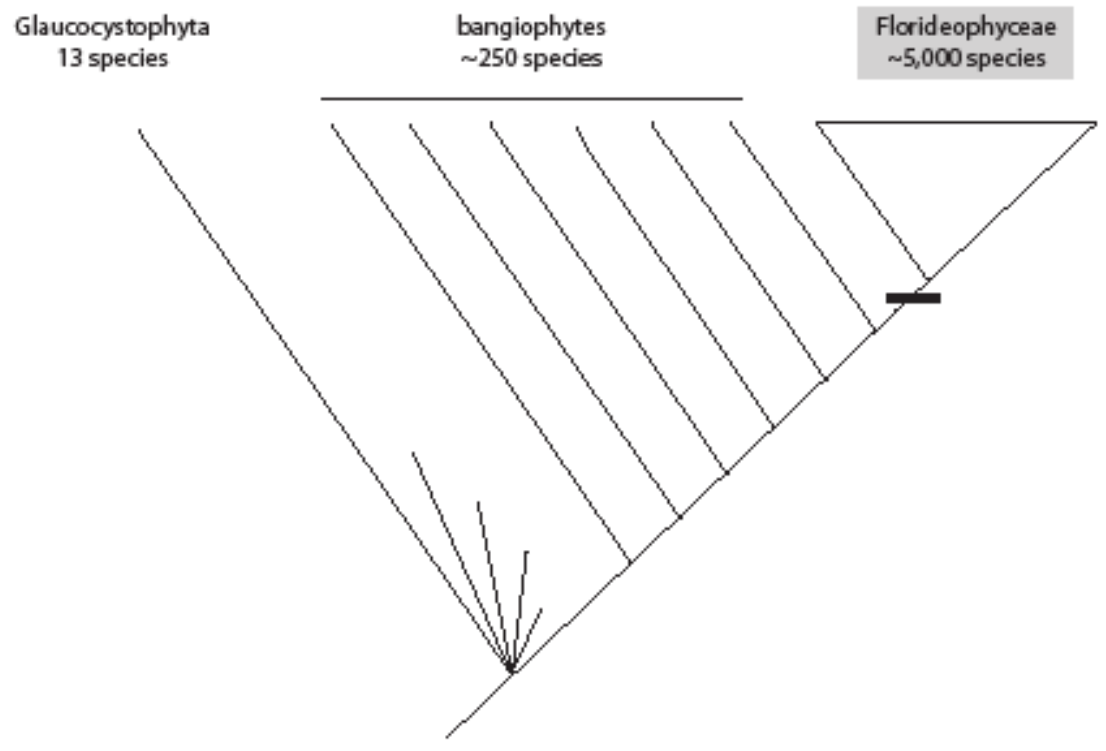

Figure 1. 


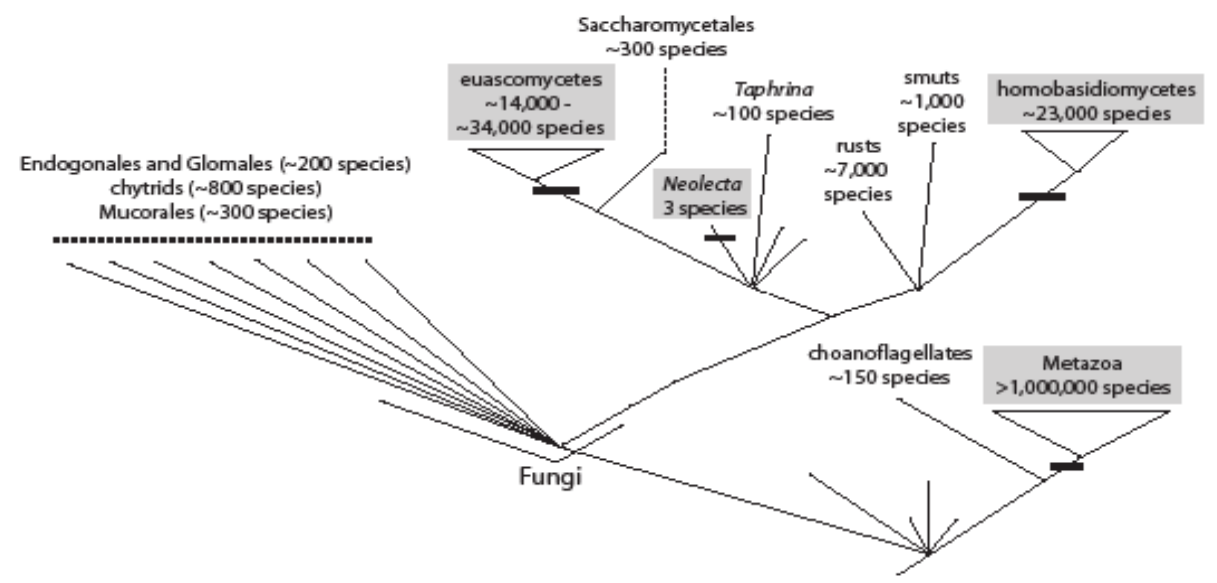

Figure 2. 

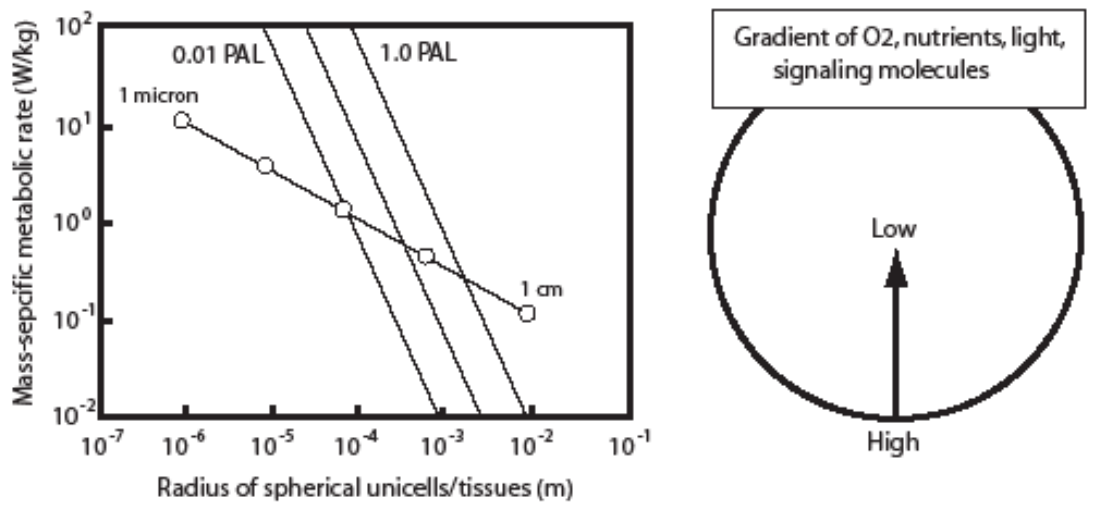

Figure 3. 


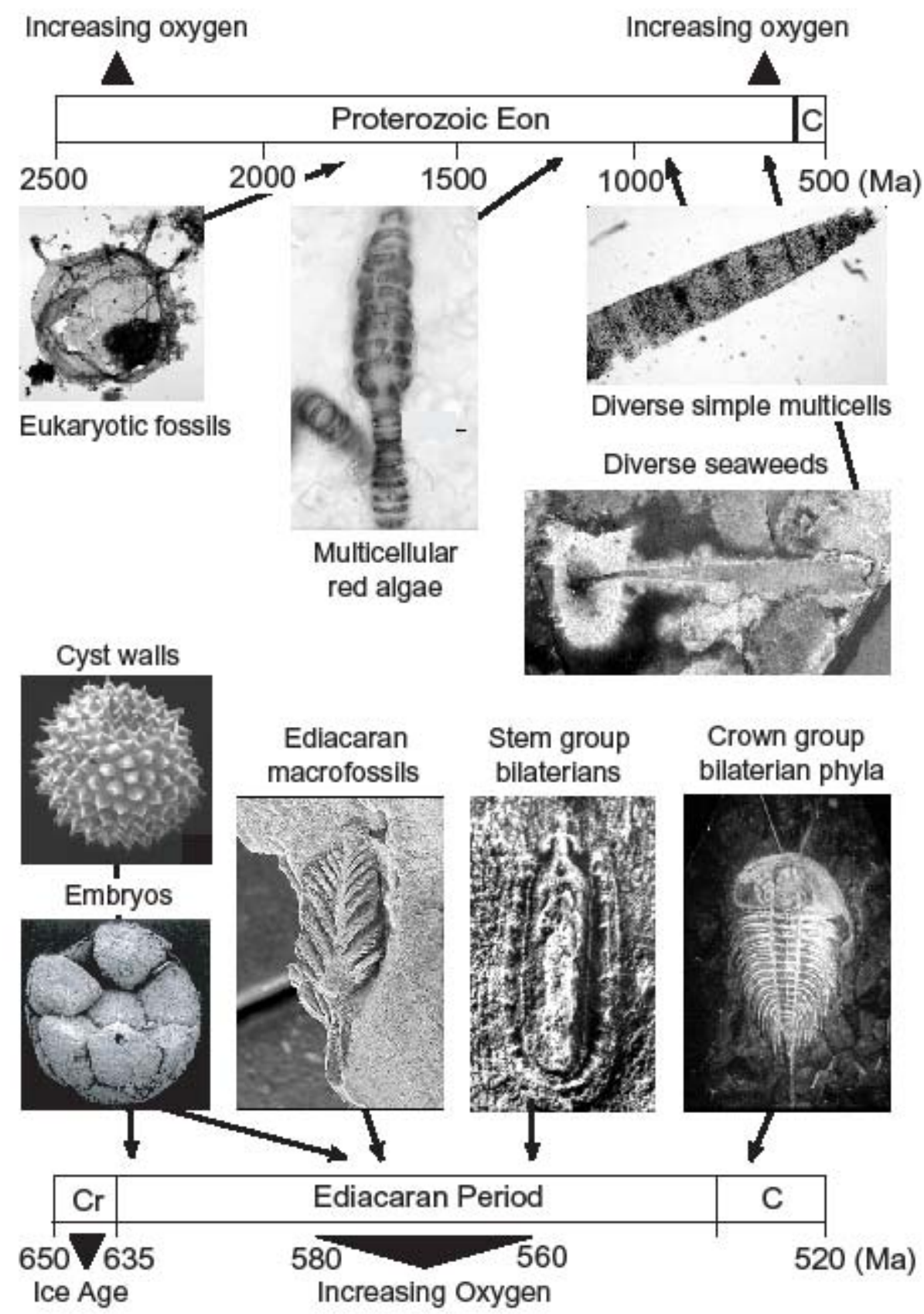

